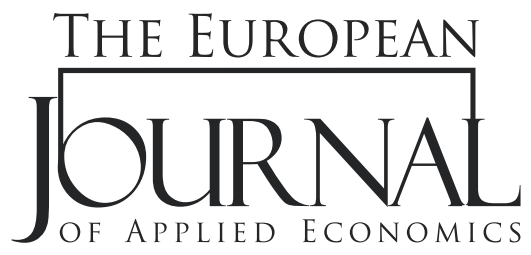

\title{
IS THERE ANY GOVERNMENT DEBT THRESHOLD IN FOUR SELECTED CENTRAL EUROPEAN COUNTRIES?
}

\author{
Yu Hsing* \\ Southeastern Louisiana University, \\ College of Business, \\ Department of Management \& Business Administration, \\ Hammond, Louisiana, \\ USA
}

\section{Abstract:}

This article shows that there is no government debt threshold in Hungary and Slovakia and that the respective government debt thresholds in Czechia and Poland are estimated to be $27.51 \%$ and $46.86 \%$, which are far smaller than the $90 \%$ threshold suggested by Reinhart and Rogoff. Hence, the Reinhart-Rogoff threshold is not applicable to Czechia, Hungary, Poland and Slovakia.

\section{Article info:}

Received: December 14, 2020

Correction: January 12, 2021

Accepted: February 12, 2021

\section{Keywords:}

fiscal expansion, government debt, Reinhart-Rogoff threshold, production function.

\section{JEL Classification:}

E62

\section{INTRODUCTION}

During the 2008-2009 global financial crisis, many countries pursued fiscal expansion in order to rescue their economies. For example, during 2008-2009, Czechia increased the government debt ratio from $28.25 \%$ to $33.56 \%$. Hungary's government debt ratio rose from $71.24 \%$ to $77.47 \%$. Poland's debt ratio went up from $46.30 \%$ to $49.43 \%$. Slovakia raised the debt ratio from $28.46 \%$ to $36.29 \%$. These debt ratios continued to rise up until 2011 in Hungary and 2013 in Czechia, Poland and Slovakia. Whether an increase in the government debt ratio raises or haram the growth rate of real GDP has been studied extensively. Reinhart and Rogoff (2010a, 2010b) show that the turning point or threshold of the government debt ratio is $90 \%$. Above $90 \%$, a higher debt ratio tends to reduce the growth rate.

The objective of this paper is to determine whether the Reinhart-Rogoff proposal may apply to four selected Central European countries, namely, Czechia, Hungary, Poland and Slovakia. 
Is it possible to have a threshold or turning point of $90 \%$ for these four countries with debt ratios less than $90 \%$ ? This paper differs from most previous studies in several aspects. First, a theoretical model based on an extended production function is presented. Second, a quadratic function is applied to test whether an inverted U-shape relationship is achievable. Third, the GARCH model is used in order to detect possible conditional heteroskedasticity in time series data.

\section{LITERATURE REVIEW}

Based on the data of forty-four countries covering about 200 years, Reinhart and Rogoff (2010a, 2010b) and Reinhart, Reinhart and Rogoff (2012) find that the growth rate and the debt ratio have a weak relationship when the government debt ratio is smaller than $90 \%$ whereas a government debt ratio above $90 \%$ causes the growth rate to decline. This threshold for the government debt ratio is similar in advanced and emerging countries. However, using the same sample constructed by Reinhart and Rogoff and other specifications, Minea and Parent (2012) find that the turning point for the government debt ratio is 115\%. Herndon, Ash and Pollin (2014) use the same data and find that for 20 advanced countries, the negative impact of the debt ratio above $90 \%$ on the growth rate cannot be confirmed. According to Herndon, Ash and Pollin, during 1946-2009, countries with the debt ratios above 90\% recorded a growth rate of $2.2 \%$ instead of $-0.1 \%$ as claimed by Reinhart and Rogoff. The impact of the debt ratio on the growth rate varies substantially across countries and periods. Égert (2015a, 2015b) could not confirm the $90 \%$ debt threshold, indicating that the threshold was in the range of $20 \%-60 \%$. A nonlinear relationship is sensitive to the specifications of the model. Parameter estimates differ by country. Lee, Park, Seo and Shin (2017) find no support for the $90 \%$ debt threshold. Using the post-WWII data developed by Reinhart and Rogoff, they indicate that the debt threshold is around 30\%. Above 30\%, the growth rate will decline by 1 percentage point.

Based on the data for eighteen OECD countries during 1980-2008, Cecchetti, Mohanty and Zampolli (2011) find that the debt threshold is $85 \%$, indicating that a higher government debt ratio above $85 \%$ tends to have a negative effect on the growth rate. They also show that when the corporate debt ratio is greater than $90 \%$ of GDP, an adverse impact on the growth rate is found.

Using a sample of 12 countries in the euro area, Checherita-Westphal and Rother (2012) find a debt threshold between $90 \%$ and $100 \%$, indicating that a higher government debt ratio tends to reduce the growth rate if the debt ratio is greater than $90 \%-100 \%$. The threshold starts in the range of $70 \%-80 \%$ based on the confidence interval.

Based on the data for twelve countries in the euro area, Baum, Checherita-Westphal and Rother (2013) find that a higher debt ratio increases the growth rate but has no impact when the debt ratio reaches about $67 \%$. When the debt ratio is greater than $95 \%$, a higher debt ratio reduces the growth rate.

Afonso and Jalles (2013) examine the relationship between government debt and economic growth for 155 advanced and developing countries during 1970 - 2008. The debt threshold is estimated to be $59 \%$ for the euro zone and $79 \%$ for emerging economies. If the debt ratio increases $10 \%$, the growth rate would decrease by $0.2 \%$ if the debt ratio is over $90 \%$ and increase by $0.1 \%$ if the debt ratio is below $30 \%$.

Chirwa (2020) studies the relationship among government debt, growth and other related variables for ten countries in the euro area. The threshold is estimated to be $70 \%$ in the long run whereas more government debt has a negative effect on the growth rate in the short run. 
Woo and Kumar (2015) reveal that if the initial debt ratio rises by 10 percentage points, the growth rate of real per capita GDP tends to reduce by 0.2 percentage points. A higher initial government debt ratio tends to cause a larger negative effect. The negative effect is the result of decrease in labor productivity growth.

Lechtenberg (2017) analyzes the subject using a sample of 10 countries. Australia, Canada, Chile, Germany and New Zealand have had low and declining debt ratios, and a higher debt ratio has not caused a decline in economic growth of these countries. On the other hand, debt thresholds are detected for several advanced countries such as the USA, the UKU, France, Greece, and Italy. A higher debt ratio beyond the threshold tends to reduce economic growth in Greece, Italy, the UK and the USA but increase economic growth rate for France.

Yared (2019) examines the trend of growing government debt, analyzes causes, and provides answers to the issue concerned. He indicates that fiscal rules are needed for policymakers not to spend beyond means and provide flexible measures to react to economic crises.

Based on the data consisting of many developing and advanced countries, Swamy (2020) reveals that if the debt ratio rises by 10 percentage points, the average growth rate will decline by 23 basis points and that government debt and economic growth have a nonlinear relationship. The effect of government debt on the growth rate varies by country, depending upon several major macroeconomic factors and debt regimes.

Jacobs, Ogawa, Sterken and Tokutsu (2020) explore the impact of government debt on the economic growth rate for 27 European Union members and 4 OECD countries during 1995-2013. They show that economic growth Granger causes government debt, but government debt does not cause Granger economic growth. Slow economic growth causes more government debt. In high-debt economies, slow economic growth increases government debt, which causes a higher interest rate in the long run, dampens interest-rate sensitive private spending, and increases public debt. In addition, they indicate that high-debt economies show greater impacts of the growth rate on the debt ratio and that low-debt countries exhibit greater effects of the debt ratio on the growth rate.

\section{THEORETICAL MODEL}

Based on the studies of Ram (1986, 1989), Goel, Payne and Ram (2008) and others, we can express the growth rate of real GDP as:

$\dot{Y}=x(\dot{L}, \dot{K}, D)$

Where

$Y=$ real GDP,

$L=$ labor employment,

$K=$ capital,

$\dot{Y}=$ the growth rate of $Y$,

$\dot{L}=$ the growth rate of $L$,

$\dot{K}=$ the growth rate of $K$, and

$D=$ the ratio of government debt to GDP. 
Because data for capital is not available, the growth rate of capital can be substituted by the ratio of investment spending to Y (IY) (Ram, 1986, 1989).

$$
\dot{Y}=w(\dot{L}, I Y, D)
$$

In a linear form, the coefficient of $\dot{L}$ measures the percent change in output over the percent change in labor, and the coefficient of $I Y$ represents the partial derivative of $Y$ with respect to $K$. The coefficients of the first two explanatory are expected to be positive, and the coefficient of the debt ratio is unclear. A lower and rising government debt ratio for infrastructural improvements may be conducive to economic growth whereas a higher and rising debt ratio may cause the interest rate to rise, crowd out consumption and investment spending, cause the local currency to appreciate, and hurt exports.

$\dot{Y}$ and the debt ratio may exhibit an inverted U-shaped relationship. In that case, we can consider the following equation:

$$
\dot{Y}=\pi_{0}+\pi_{1} \dot{L}+\pi_{2} I Y+\pi_{3} D+\pi_{4} D^{2}+\varepsilon
$$

If there is an inverted U-shaped relationship between $\dot{Y}$ and the debt ratio, the coefficient of $D$ should be positive, and the coefficient of $D^{2}$ should be negative.

The turning point of the debt ratio is given by:

$$
D^{*}=\pi_{3} / 2 \pi_{4}
$$

where $\pi_{3}$ is the coefficient of $D$ and $\pi_{4}$ is the coefficient of $D^{2}$.

\section{EMPIRICAL RESULTS}

The sources of data came from the International Financial Statistics, the Eurostat, and the World Economic Outlook. The growth rate of real gross domestic product (GDP) or labor employment is expressed as a percent. Investment spending as a percent of GDP is used as data for capital is not available. Government debt as a percent of GDP is used. This study covers the sample period from 1995 or 1996 to 2019. Data for the government debt ratio or the growth rate before 1995 or 1996 is not available.

Figure 1 exhibits scatter diagrams between the economic growth rate and the government debt ratio for these four countries during the sample period. It seems that the government debt ratio and the economic growth rate in Czechia or Poland have a nonlinear relationship whereas the government debt ratio and the economic growth rate in Hungary and Slovakia shows a negative or an unclear relationship. Hypothesis testing is required as to determine whether the above observations can be verified statistically.

Table 1 presents the estimated regressions and related statistics. Two versions with and without the quadratic term are estimated for each country. For Czechia, in version A, the quadratic term is negative and statistically significant at $1 \%$ level. The threshold or turning point is estimated to be $27.51 \%$. A further increase in the debt ratio beyond the threshold reduces the growth rate. In version B without the quadratic term, the debt ratio has a positive and significant coefficient, which makes us draw a misleading conclusion that the government can continue increasing the debt ratio and generate a positive impact on the economic growth rate. 

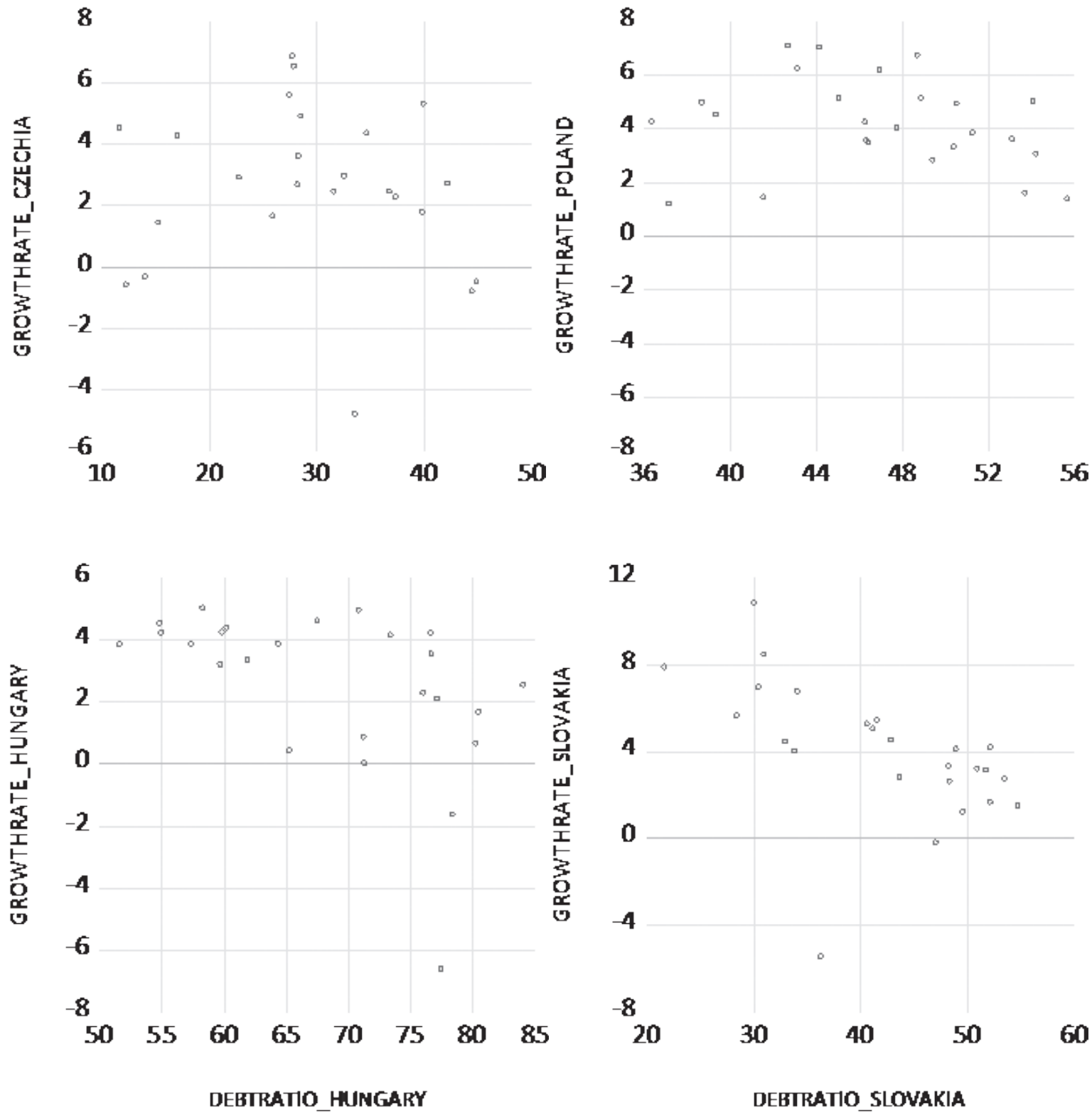


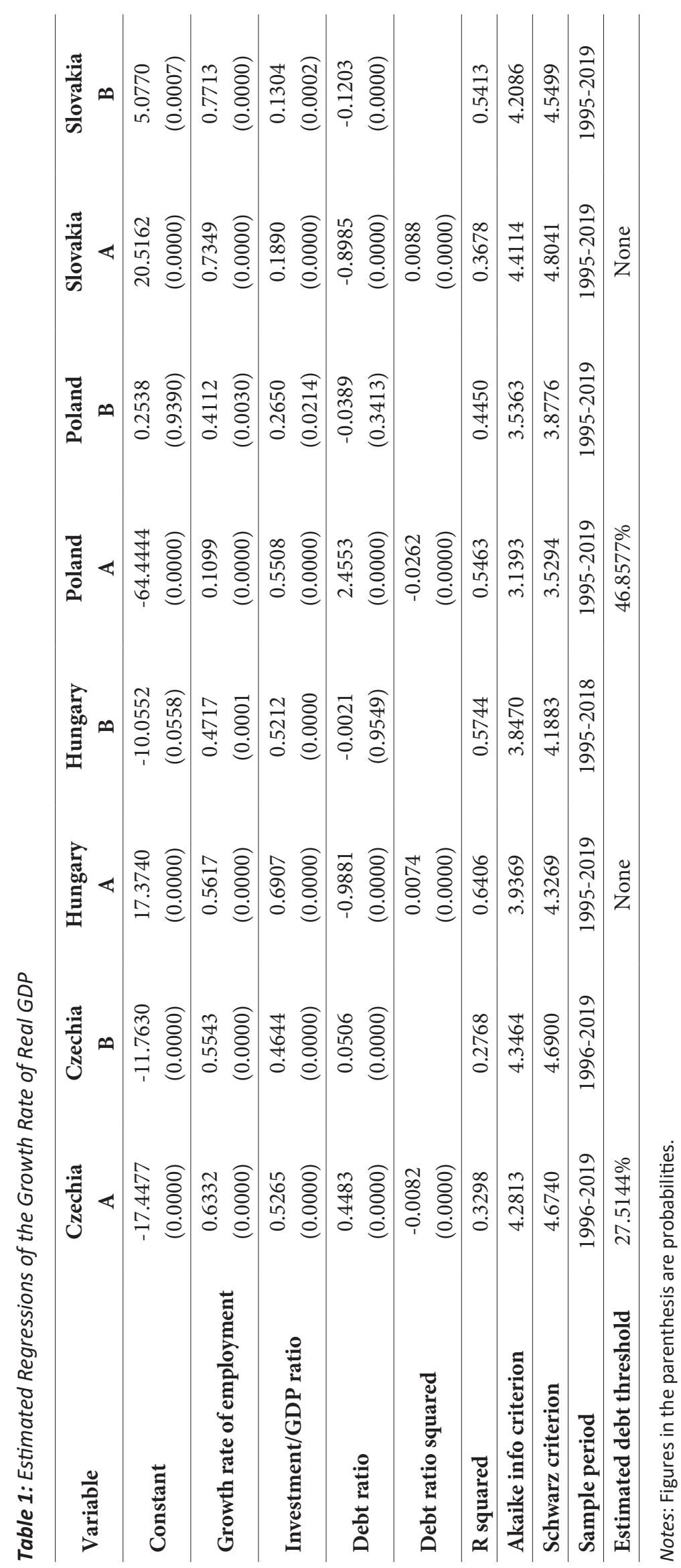


For Hungary, in version A with the quadratic term, all coefficients are significant. However, a positive significant sign of the quadratic term suggests that the government debt ratio and the growth rate exhibit a U-shape correlation, which is contrary to economic theory. In version B without the quadratic term, a coefficient of the government debt ratio is negative and insignificant at $10 \%$ level. In comparison, the findings by Hsing (2018) cannot be compared with the result in this paper because real GDP instead of the percent change in real GDP, is chosen as the dependent variable.

For Poland, in version A, a coefficient of the quadratic term is negative and significant at $1 \%$ level. The threshold of the debt ratio is calculated to be $46.86 \%$. A higher government debt ratio than this threshold tends to reduce the growth rate. In version B without the quadratic term, a coefficient of the government debt ratio is negative and insignificant at $10 \%$ level. If version B is chosen, we may draw a misleading conclusion that a higher government debt ratio will not be harmful to the growth rate.

For Slovakia, in version A with the quadratic term, a negative significant sign of the debt ratio and a positive significant sign of the quadratic term indicate a $U$-shape relationship, which is inconsistent with economic theory. In version B without the quadratic term, a negative significant sign of the government debt ratio suggests that a higher government debt ratio causes the growth rate to decline regardless of the level of debt ratio.

In comparison, the findings in this paper are different from and similar to some of previous studies. Reinhart and Rogoff (2010a, 2010b) show that the threshold for the debt ratio is $90 \%$ whereas the respective thresholds of debt ratio for Czechia and Poland are estimated to be $27.51 \%$ and $46.86 \%$. The results for Hungary (Version A) and Slovakia (Versions A and B) are consistent with Kumar and Woo (2015) and Swamy (2020), who indicate that the debt ratio has a negative impact on the growth rate. The thresholds reported by Cecchetti, Mohanty and Zampolli (2011), Checherita-Westphal and Rother (2012), Minea and Parent (2012), Afonso and Jalles (2013), Baum, Checherita-Westphal, and Rother (2013), and Chirwa (2020) are higher than the respective thresholds of $27.51 \%$ and $45.26 \%$ for Czechia and Poland. The estimated thresholds for Czechia and Poland are close to the $30 \%$ debt threshold found by Lee, Park, Seo and Shin (2017), the threshold between $20 \%$ and $60 \%$ estimated by Égert (2015a, 2015b), and the threshold of 47.45\% for Italy reported by Lechtenberg (2017).

\section{SUMMARY AND CONCLUSIONS}

This article has studied the impact of the government debt ratio on the growth rate of real GDP for Czechia, Hungary, Poland and Slovakia using an extended production function. The growth rate is specified as function of the percent change in labor employment, the ratio of investment spending to nominal gross domestic product, and the government debt ratio. A quadratic form is used for the debt ratio to test whether a nonlinear inverted U-shape relationship exists.

The results have confirmed that Czechia or Poland exhibits a threshold or turning point whereas Hungary and Slovakia do not show an inverted U-shape relationship. The threshold for Czechia is estimated to be $27.51 \%$. The growth rate and the government debt ratio have a positive relationship when the debt ratio is up to $27.51 \%$ whereas they have a negative relationship when the government debt ratio is greater than $27.51 \%$. The estimated threshold for Poland is $46.86 \%$, suggesting that a higher government debt ratio beyond $46.86 \%$ tends to reduce economic growth. 
These results have some policy implications. An analysis of data indicates that debt ratios in these four countries show declining trends. For example, the debt ratio in Czechia declined from $44.91 \%$ in 2013 to $31.62 \%$ in 2019. The debt ratio in Hungary declined from $80.48 \%$ to $67.52 \%$. The debt ratio in Poland dropped from $54.23 \%$ to $47.77 \%$ in 2019 . The debt ratio in Slovakia decreased from $54.74 \%$ in 2013 to 48.35\% in 2019. Debt ratios in Czechia and Poland declined and moved toward the respective thresholds of $27.51 \%$ and $46.86 \%$, suggesting that the direction of changes in debt ratio is justified. Lower debt ratios in Hungary and Slovakia in recent years have also helped to raise the growth rate as the debt ratio has an adverse effect on the economic growth rate as shown in the estimated regression with the quadratic term in Hungary and the regression with or without the quadratic term in Slovakia.

\section{REFERENCES}

Afonso, A., \& Jalles, J. T. (2013). Growth and productivity: The role of government debt. International Review of Economics and Finance, 25, 384-407. https://doi.org/10.1016/j.iref.2012.07.004

Asteriou, D., Pilbeam, K. \& Pratiwi, C. E. (2021). Public debt and economic growth: panel data evidence for Asian countries. Journal of Economics and Finance, 45, 270-287. https://doi.org/10.1007/s12197-020-09515-7

Azzimonti, M. \& Yared, P. (2017). A Note on optimal fiscal policy in an economy with private borrowing limits. Economics Letters, 151, 62-65. https://doi.org/10.1016/j.econlet.2016.12.007

Baum, A., Checherita-Westphal, C., \& Rother, P. (2013). Debt and growth: New evidence for the euro area. Journal of International Money and Finance, 32, 809-821. https://doi.org/10.1016/j.jimonfin.2012.07.004

Bhandari, A., Evans, D., Golosov, M. \& Sargent, T. J. (2017a). Fiscal policy and debt management with incomplete markets. Quarterly Journal of Economics, 132(2), 617-663. https://doi.org/10.1093/qje/qjw041

Bhandari, A., Evans, D., Golosov, M. \& Sargent, T. J. (2017b). Public debt in economies with heterogenous agents. Journal of Monetary Economics, 91, 39-51. https://doi.org/10.1016/j.jmoneco.2017.09.007

Brady, G. L. \& Magazzino, C. (2018). Government debt in EMU countries. The Journal of Economic Asymmetries, 18, e00096. https://doi.org/10.1016/j.jeca.2018.e00096

Cecchetti, S. G., Mohanty, M.S., \& Zampolli, F. (2011). The real effects of debt. [Working Papers No. 352.] Basel, Switzerland: Bank for International Settlements. Retrieved from: https://www.bis.org/publ/othp16.pdf

Checherita-Westphal, C., \& Rother, P. (2012). The impact of high government debt on economic growth and its channels: An empirical investigation for the euro area. European Economic Review, 56(7), 1392-1405. https://doi.org/10.1016/j.euroecorev.2012.06.007

Chirwa, T. G. \& Odhiambo, N.M. (2020). Public debt and economic growth nexus in the Euro area: A dynamic panel ARDL approach. Scientific Annals of Economics and Business, 67(3), 291-310. http://dx.doi.org/10.47743/ saeb-2020-0016

Chudik, A., Mohaddes, K., Pesaran, M. H. \& Raissi, M. (2017). Is there a debt-threshold effect on output growth? Review of Economics and Statistics, 99(1), 135-150. https://doi.org/10.1162/REST_a_00593

Dreger, C. \& Reimers, H.-E. (2013). Does euro area membership affect the relation between gdp growth and public debt? Journal of Macroeconomics, 38(B), 481-486. https://doi.org/10.1016/j.jmacro.2013.07.012

Eberhardt, M. \& Presbitero, A. F. (2015). Public debt and growth: Heterogeneity and non-linearity. Journal of International Economics, 97(1), 45-58. https://doi.org/10.1016/j.jinteco.2015.04.005

Égert, B. (2015a). The 90\% public debt threshold: the rise and fall of a stylized fact". Applied Economics, 47(34-35), 3756-3770. https://doi.org/10.1080/00036846.2015.1021463

Égert, B. (2015b). Public debt, economic growth and nonlinear effects: Myth or reality? Journal of Macroeconomics, 43, 226-238. https://doi.org/10.1016/j.jmacro.2014.11.006

Goel, R. K., Payne, J. E., \& Ram, R. (2008). R\&D expenditures and US economic growth: A disaggregated approach. Journal of Policy Modeling, 30(2), 237-250. https://doi.org/10.1016/j.jpolmod.2007.04.008 
Gómez-Puig, M. \& Sosvilla-Rivero, S. (2015). The Causal Relationship between Public Debt and Economic Growth in EMU Countries. Journal of Policy Modeling, 37(6), 974-989. https://doi.org/10.1016/j.jpolmod.2015.09.004

Grembi, V., Nannicini, T. \& Troiano, U. (2016). Do fiscal rules matter? American Economic Journal: Applied Economics, 8(3), 1-30. https://doi.org/10.1257/app.20150076

Gunarsa, S., Makin, T. \& Rohde, N. (2019). Public debt in developing Asia: A help or hindrance to growth? Applied Economics Letters, 27(17), 1400-1403. https://doi.org/10.1080/13504851.2019.1683147

HÈbert, B. \& Schreger, J. (2017). The costs of sovereign default: Evidence from Argentina. American Economic Review, 107(10), 3119-3145. https://doi.org/10.1257/aer.20151667

Herndon, T., Ash, M., \& Pollin, R. (2014). Does high public debt consistently stifle economic growth? A critique of Reinhart and Rogoff. Cambridge Journal of Economics, 38(2), 257-279. https://doi.org/10.1093/cje/bet075

Hsing, Y. (2020). Does the Reinhart-Rogoff hypothesis apply to China? Economics Bulletin, 40(4), 2663-2668

Hsing, Y. (2020) On the relationship between economic growth and government debt for Bulgaria. Test of the Reinhart-Rogoff hypothesis. Theoretical and Applied Economics, 27( 4(625)), 5-12. Retrieved from: http:// store.ectap.ro/articole/1502.pdf

Hsing, Y. (2018). Test of a quadratic relationship between aggregate output and government debt in Hungary. The European Journal of Applied Economics, 15(1), 38-45. https://doi.org/10.5937/EJAE15-15684

Jacobs, J., Ogawa, K., Sterken, E., \& Tokutsu, I. (2020). Public debt, economic growth and the real interest rate: A panel VAR Approach to EU and OECD countries. Applied Economics, 52(12), 1377-1394. https://doi. org/10.1080/00036846.2019.1673301

Kempa, B. \& Khan, N. S. (2016). Government debt and economic growth in the G7 countries: Are there any causal linkages? Applied Economics Letters, 23(6), 440-443. https://doi.org/10.1080/13504851.2015.1080797

Kourtellos, A., Stengos, T. \& Tan, C. M. (2013). The effect of public debt on https://doi.org/10.1080/13504851.201 5.1080797 growth in multiple regimes. Journal of Macroeconomics, 38(A), 35-43. https://doi.org/10.1016/j. jmacro.2013.08.023

Kum, H. \& Oktem, O. (2018). Government debts and economic growth: The case for selected EU countries. International Journal of Economics and Financial Issues, 8(6), 192-196. Retrieved from: https://www. econjournals.com/index.php/ijefi/article/view/7399/pdf

Lechtenberg, L. (2017). The debt-to-Threshold effect on output: A country specific analysis. Aisthesis, the Interdisciplinary Honors Journal, 8 (1), 26-34. Retrieved from: https://pubs.lib.umn.edu/index.php/aisthesis/ article/view/39

Lee, S., Park, H., Seo, M. H., \& Shin, Y. (2017) Testing for a debt-threshold effect on output growth. Fiscal studies, 38(4), 701-717. https://doi.org/10.1111/1475-5890.12134

Lof, M. \& Malinen, T. (2014). Does sovereign debt weaken economic growth? A panel VAR analysis. Economics Letters, 122(3), 404-407. https://doi.org/10.1016/j.econlet.2014.10.030

Minea, A., \& Parent, A. (2012). Is high public debt always harmful to economic growth? Reinhart and Rogoff and some complex nonlinearities [Working paper, 12-08]. Restinclières, France: Association Française de Cliométrie (AFC)

Ram, R. (1986). Government size and economic growth: A new framework and some evidence from cross-section and time-series data. The American Economic Review, 76(1), 191-203.

Retrieved from: https://www.jstor.org/stable/1804136?seq=1

Ram, R. (1989). Government size and economic growth: A new framework and some evidence from cross-section and time-series data: Reply. The American Economic Review, 79(1), 281-284.

Reinhart, C. M., \& Rogoff, K. S. (2010a). Growth in a time of debt. American Economic Review, 100(2), 573-78. https://doi.org/10.1257/aer.100.2.573

Reinhart, C. M., \& Rogoff, K. S. (2010b). Debt and growth revisited. [MPRA Paper No. 24376]. Munich: Munich University Library. 
Shahor, T. (2018). The impact of public debt on economic growth in the Israeli economy. Israel Affairs, 24(2), 254-264. https://doi.org/10.1080/13537121.2018.1429547

Panizza, U. \& Presbitero, A. F. (2013). Public debt and economic growth in advanced economies: A Survey. Swiss Journal of Economics and Statistics, 149(2), 175-204. Retrieved from: https://sjes.springeropen.com/track/ pdf/10.1007/BF03399388.pdf

Panizza, U. \& Presbitero, A. F. (2014). Public debt and economic growth: Is there a causal effect? Journal of Macroeconomics, 41, 21-41. https://doi.org/10.1016/j.jmacro.2014.03.009

Pegkas, P. (2018). The effect of government debt and other determinants on economic growth: The Greek experience. Economies, 6(1), 1-19. https://doi.org/10.3390/economies6010010

Puente-Ajovín, M. \& M. Sanso-Navarro. (2015). Granger causality between debt and growth: Evidence from OECD Countries. International Review of Economics and Finance, 35, 66-77. https://doi.org/10.1016/j. iref.2014.09.007

Reinhart, C. M., Reinhart, V. R. \& Rogoff, K. S. (2012). Public Debt Overhangs: Advanced-Economy Episodes since 1800. Journal of Economic Perspectives, 26(3), 69-86. https://doi.org/10.1257/jep.26.3.69

Swamy, V. (2020). Debt and growth: Decomposing the cause-and-effect relationship. International Journal of Finance \& Economics, 25, 141-156. https://doi.org/10.1002/ijfe.1729

Woo, J., \& Kumar, M. S. (2015). Public debt and growth. Economica, 82(328), 705-739. https://doi.org/10.1111/ecca.12138

Yared, P. (2019). Rising government debt: Causes and solutions for a decades-old trend. Journal of Economic Perspectives, 33(2), 115-140. https://doi.org/10.1257/jep.33.2.115 


\section{POSTOJI LI PRAG JAVNOG DUGA U ČETIRI IZABRANE CENTRALNOEVROPSKE ZEMLJE?}

\section{Rezime:}

Ovaj rad pokazuje da u Mađarskoj i Slovačkoj ne postoji prag javnog duga i da se procenjuje da su pragovi javnog duga u Češkoj i Poljskoj $27,51 \%$ i 46,86\%, što je daleko manje od praga od $90 \%$ koji su predložili Rajnhart i Rogof. Stoga, ovaj prag nije primenljiv na Češku, Mađarsku, Poljsku i Slovačku.
Ključne reči:

fiskalna ekspanzija, javni dug, prag Rajnharta i Rogofa, proizvodna funkcija.

Klasifikacija jela:

E62 